\title{
Sistem Informasi Webstore Online Pada Toko DK Corner Menggunakan Metode Web Design Responsive Bootstrap
}

\author{
Ria Anggraini \& Andri \\ Fakultas Ilmu Komputer, Universitas Bina Darma \\ Email: riaa876@gmail.com
}

\begin{abstract}
Toko DK Corner is a trading company that specializes in selling women's daily fashion needs. Currently, the DK Corner Store records more than thousands of sales transactions every year, thus requiring the company to be able to provide ordering services for consumers to support better sales and service transactions and of course increase sales profits. The system development method used in system development is Web Engineering. To implement this sales and ordering information system, supporting components are needed in order to work properly. These components include using the PHP programming language (Personal Homepage), Bootstrap Framework and "for data storage using a MySQL database". "The design of this system is expected to help and overcome existing problems so that it can be useful for interested parties". The purpose of this research is expected with the information system is expected to make it easier for companies to promote the products on offer and make it easier to make online sales transactions so that they can be done anytime and safely, and can increase sales.
\end{abstract}

Keywords: Information system, web engineering

\section{Pendahuluan}

Perkembangan teknologi informasi dari tahun ketahun yang semakin cepat menjadi tantangan berat bagi pengguna teknologi informasi itu sendiri dan mendorong setiap sektor organisasi baik formal maupun informal atau lembaga-lembaga lainnya untuk dapat memanfaatkannya sebagai penunjang kegiatan kerja sehingga dapat menghasilkan informasi yang cepat, tepat dan akurat.

Toko DK Corner merupakan usaha yang bergerak dalam bidang penjualan terutama kebutuhan fashion wanita sehari hari yang saat ini sedang berkembang pesat di Kota Lubuklinggau dan telah memiliki banyak pelanggan di kota Lubuklinggau .

Pengolahan data yang masih menggunakan sistem secara konvensional sering menimbulkan masalah dalam perusahaan, diantaranya adalah penduplikatan data yaitu data yang sama dapat dimasukkan secara berulang-ulang, sulitnya untuk memperoleh data persediaan barang, data penjualan, dan data-data lain yang dibutuhkan. Selain itu, keterlambatan dalam pembuatan laporan juga sering terjadi karena kesulitan dalam pencarian dan pengolahan data. Permasalahan lainnya yaitu toko harus menunggu pelanggan untuk datang ke toko agar dapat memberikan informasi kepada pelanggan apa saja produk yang dijual di Toko DK Corner dan ini sangat tidak praktis dan lambatnya toko dalam meningkatkan penjualan.

Permasalahan-permasalahan yang timbul disebabkan karena perusahaan belum mengoptimalkan pemakaian komputer agar informasi yang dihasilkan lebih akurat seperti penyajian laporan persediaan dan penjualan produk. Solusi terbaik dari masalah di atas adalah dibangun suatu sistem informasi penjualan berbasis web yang dapat diakses secara online sehingga pelanggan dari daerah maupun luar daerah dapat 
menjangkau informasi mengenai toko, melakukan transaksi penjualan serta mengetahui kebutuhan dan keinginan pelanggan. Dengan adanya sistem berbasis web secara online toko dapat langsung mengenalkan produk kepada pelanggan tanpa terkendala jarak dan waktu serta toko dapat bertransaksi serta memasarkan produknya secara cepat dan aktif 24 jam non stop tanpa harus menutup toko.

Berdasarkan latar belakang penulis tertarik untuk melakukan penelitian tentang bagaimana membangun Sistem Informasi webstore online sehingga pelanggan dapat langsung bertransaksi dengan toko dimana saja dankapan saja. Kemudian pada Toko DK Corner dapat membantu dalam mengurangi kesalahan dalam pengolahan data serta dapat meningkatkan keuntungan serta mengenalkan produknya tidak hanya di kota Lubuklinggau saja.

\section{Tinjauan Literatur}

\subsection{Bootstrap}

Bootstrap adalah sebuah framework yang dikembangkan pengembang Twitter pada pertengahan tahun 2010. Sebelum menjadi kerangka kerja open-source, Bootstrap dikenal sebagai Twitter Blueprint. Dan terus berkembang sampai saat ini dan Bootstrap telah menjadi salah satu front-end framework yang paling populer dan merupakan proyek open source di dunia. Platform ini awalnya dikembangkan pada ajang Hackweek, sebuah perhelatan developer yang diadakan Twitter. Bootstrap digambarkan sebagai CSS sederhana namun dibangun dengan pre-processor yang menyediakan lebih banyak daya dan fleksibilitas ketimbang CSS standar. Awalnya dirilis pada Jumat, 19 Agustus, 2011, dan sudah memiliki lebih dari 20 produk release termasuk yang terbesar adalah versi 2 dan versi 3. Fungsionalitas responsif terhadap seluruh kerangka sebagai stylesheet opsional dapat ditemukan ada Bootsrap (Adhiasta, M. R., \& Muhammad Kusban, S. T. (2016).

\subsection{PHP}

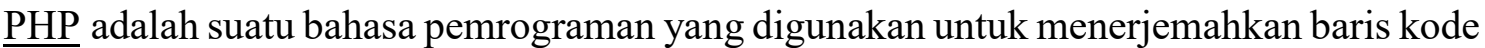
program menjadi kode mesin yang dapat dimengerti oleh komputer yang berbasis serverside yang dapat ditambahkan ke dalam HTML" (Supon, Dkk. 2016).

PHP adalah Bahasa server-side -scripting yang menyatu dengan HTML untuk membuat halaman web yang dinamis. Karena PHP merupakan server-side-scripting maka sintaks dan perintah-perintah PHP akan diesksekusi diserver kemudian hasilnya akan dikirimkan ke browser dengan format HTML (Arief, 2011).

\subsection{MySQL (My Structure Query Language)}

MySQL (My Structure Query Language) atau yang biasa dibaca my se-kuel adalah sebuah program pembuat dan pengelola database atau yang sering disebut DBMS (DataBase Management System). Sifat dari DBMS ini adalah open source. MySQL sebenarnya produk yang berjalan pada platform Linux, dengan adanya perkembangan dan banyaknya pengguna serta lisensi dari database ini adalah open source maka para pengembang merilis versi Windows. (Nugroho, 2008)

\subsection{Unified Modelling Language (UML)}


Pada perkembangan teknik pemrograman berorientasi objek, muncullah sebuah standarisasi bahasa pemodelan untuk pembangunan perangkat lunak yang dibangun dengan menggunakan teknik pemrograman berorientasi objek, yaitu Unified Modelling Language (UML). UML muncul karena adanya kebutuhan pemodelan visual untuk menspesifikasikan, menggambarkan, membangun, dokumentasi dari suatu perangkat lunak. UML merupakan bahasa visual untuk pemodelan dan komunikasi mengenai sebuah sistem dengan menggunakan diagram dan teks-teks pendukung (Rosa, Dkk, 2018).

Untuk membangun Penerapan CRM Berbasis Web dan SMS Gateway ini dibutuhkan lima diagram UML, yaitu Use Case Diagram, Activity Diagram, Class Diagram, dan Sequence Diagram (Antoni, Fikari \& Akbar, 2018; Antoni \& Akbar, 2019; Antoni, Jie \& Abareshi, 2020; Antoni, Herdiansyah, Akbar \& Sumitro, 2021).

\section{Metode Penelitian}

\subsection{Metode Pengumpulan Data}

Dalam melakukan penelitian untuk mendapatkan data dan informasi, maka teknik yang digunakan dalam proses pengumpulan data dilakukan antara lain Observasi (Fauzi, Dencik \& Asiati, 2019), Penulis melakukan pengamatan langsung ke Toko DK Corner seperti pengamatan langsung ke pelanggan yang datang, cara perusahaan menawarkan produk yang dijual, keramahan toko dalam melayani pelanggan, 2). Wawancara, Penulis melakukan bentuk komunikasi verbal kepada pemilik Toko DK Corner mengenai permasalahan seputar hubungan toko ke pelanggan, 3) Studi Literatur, Penulis mencari bahan yang mendukung dalam pendefinisian masalah, konsep-konsep dasar yang melandasi landasan teori penulis dalam melakukan penulisan skripsi ini melalui bukubuku, internet, yang erat kaitannya dengan objek permasalahan, untuk studi penulis banyak mengambil kutipan dari beberapa jurnal dan buku.

\subsection{Metode Pengembangan Sistem}

Dalam membangun sistem informasi manajemen hubungan pelanggan pada Toko DK Corner ini peneliti menggunakan metode Web Engineering. Metode ini terdiri dari Communication, Planning, Modeling, Constructions, dan Deployment. Pengembangan sistem ini dirasa sangat cocok karena bersifat sistematik berurutan dalam membangun software dan metode ini mempunyai tahapan-tahapan sebagai berikut (Nilasari, Senja. 2014)" :

1) Communication (Komunikasi), Tahap komunikasi terdiri dari tiga tahap, yaitu formulation, negociation dan elicititation." 2). Planning (Perencanaan), Tahap perencanaan terdiri dari beberapa bagian. Pertama adalah tahap estimasi yang terdiri dari waktu, biaya dan sumber daya manusia. Semua tahap sudah dilakukan estimasinya. Kedua adalah analisis resiko. Mulai dari orang, produk, dan proses. Resiko telah dilakukan analisisnya. Ketiga adalah jadwal. Penelitian ini sudah sesuai dengan jadwal yang telah direncanakan, 3) Modelling (Pemodelan), Tahap ini merupakan tahap perancangan perangkat lunak. Salah satu alat bantu yang digunakan dalam penelitian ini adalah dengan membuat use case diagram. Use case diagram merupakan alat perancangan yang digunakan untuk mengetahui apa yang dilakukan oleh pengguna, yang dalam hal ini dinamakan aktor." 4) Constructions (Kontruksi), Tahap ini untuk membangun aplikasi penjualan. Aplikasi dibangun dengan menggunakan bahasa pemrograman PHP dan database MySql. 5) 
Deployment, Tahap deployment merupakan tahap untuk memberikan peningkatan WebApp secara berkala untuk user dan mengevaluasi serta memberikan umpan balik.

\subsection{Tahap Desain}

\section{Use Case Diagram}

Use case diagram merupakan diagram yang menggambarkan semua kasus (case) yang akan ditangani oleh perangkat lunak beserta aktor atau pelakunya. Rancangan sistem yang diimplementasikan dalam bentuk diagram UML (Unified Modeling Language). Diagram Use Case untuk penerapan aplikasi ini terdapat 3 aktor yaitu Admin, Pimpinan dan Pelanggan, yang memiliki fungsi berbeda-beda. Pada bagian Admin Data yang dilibatkan yaitu Data Pengguna, Data Kota, Data Pelanggan, Data Kategori, Data Merk, Data Produk, Data Transaksi, pada bagian pimpinan yaitu login, laporan penjualan, kemudian pada bagian Pelanggan Data yang dilibatkan yaitu login sistem, registrasi sistem, melihat produk, membeli produk . Dapat dilihat pada Gambar 1.

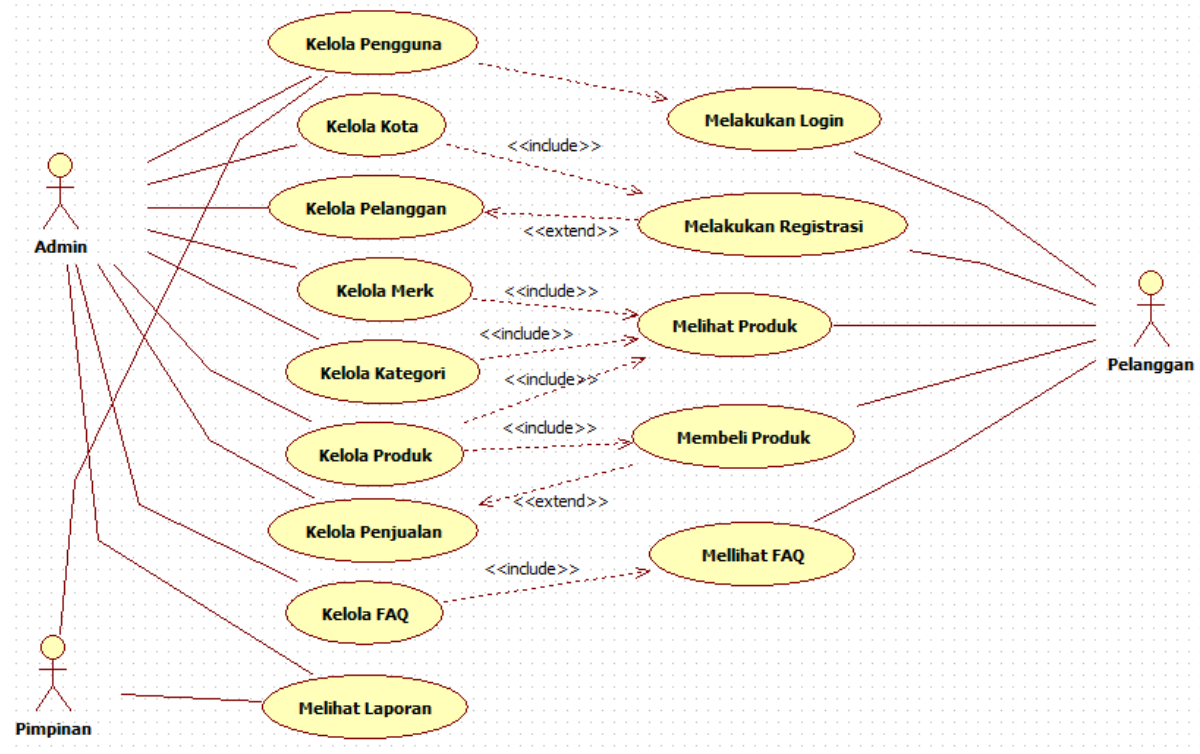

Gambar 1. Use Case Diagram Sistem

\section{Pembuatan Aplikasi}

Pembuatan Aplikasi dilakukan dengan menggunakan hardware berupa laptop dengan spesifikasi processor Core i5 2,8 Ghz, 2 GB Memory DDR 3, Harddisk 320 GB HDD. Sedangkan software yang digunakan adalah sistem operasi menggunakan Windows 7 Professional, XAMPP, terdiri atas Apache, MySQL, dan phpMyAdmin, Adobe Dreamweaver CS6, Browser Mozilla Firefox, dan Google Chrome

\section{Hasil dan Pembahasan}

Hasil yang didapatkan dari sistem informasi webstore online pada Toko DK Corner yaitu adanya aktor yang menjalankan sistem sebanyak 3 aktor yang berhak mengakses sistem yaitu Admin, Pimpinan dan Pelanggan. Setiap aktor memiliki hak akses masing-masing setiap hak akses dibuat dengan disesuaikan kebutuhan pengelola sistem. Implementasi sistem dilakukan oleh 3 aktor yang berhak mengakses sistem yaitu Admin, Pimpinan dan Pelanggan yang memiliki fungsi masing-masing kedalam sistem berbasis website, berikut 
pembahasan dari sistem yang telah dibangun.

\subsection{Antarmuka Bagi Admin}

Halaman antar muka bagi Admin merupakan halaman yang hanya admin saja dapat membuka dan melakukan pengelolaan sistem. Berikut halaman antar muka bagi Admin.

\section{Halaman Login}

Halaman Login akan tampil pertama kali jika pengelola sistem masuk ke dalam sistem. Untuk halaman Login dapat dilihat pada Gambar 2.

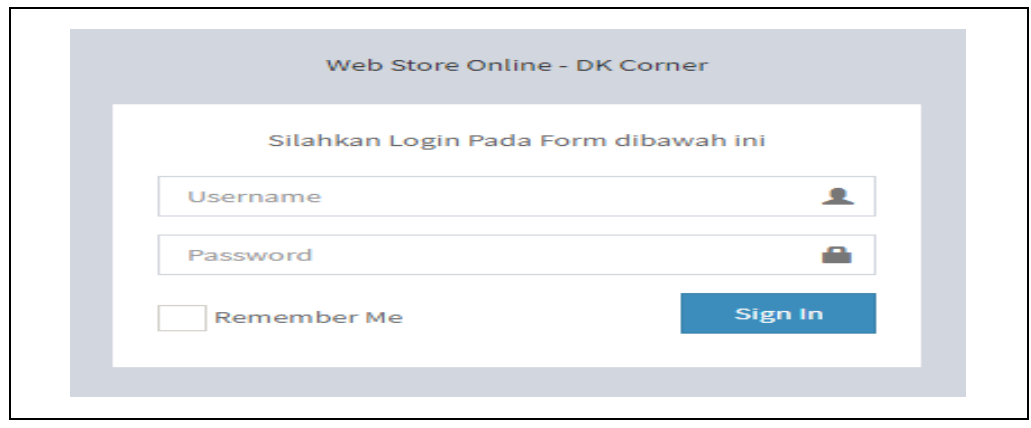

Gambar 2. Halaman Login

\section{Halaman Dashboard}

Halaman Dashboard akan tampil pertama setelah petugas berhasil login Untuk halaman Dashboard dapat dilihat pada Gambar 3.

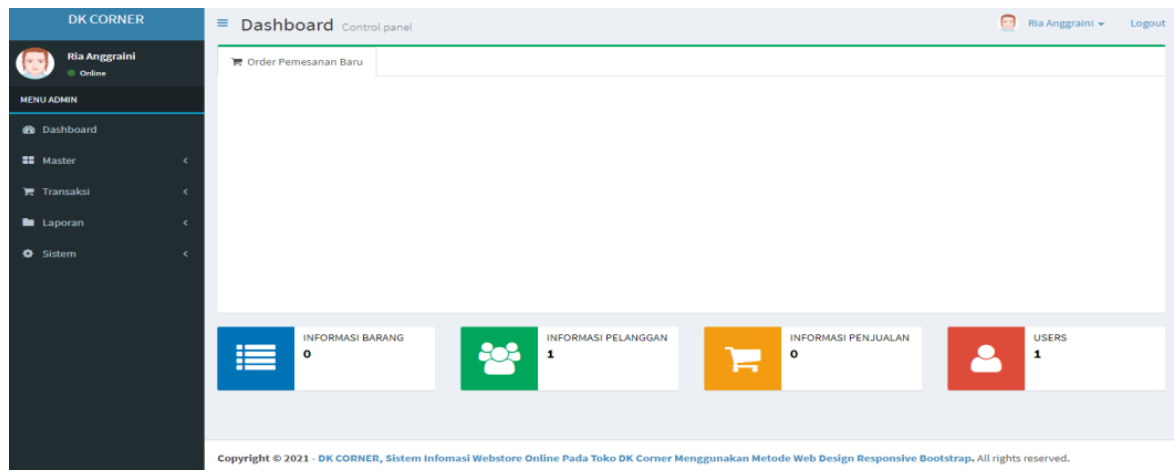

Gambar 3. Halaman Dashboard

3. Tampil Halaman Kota

Halaman data kota merupakan halaman yang diigunakan untuk menampikan informasi data kota yang akan diinput pelanggan ketika melakukan registrasi. Berikut tampilan halaman data kota terlihat pada Gambar 4.

Gambar 4. Halaman Kota 


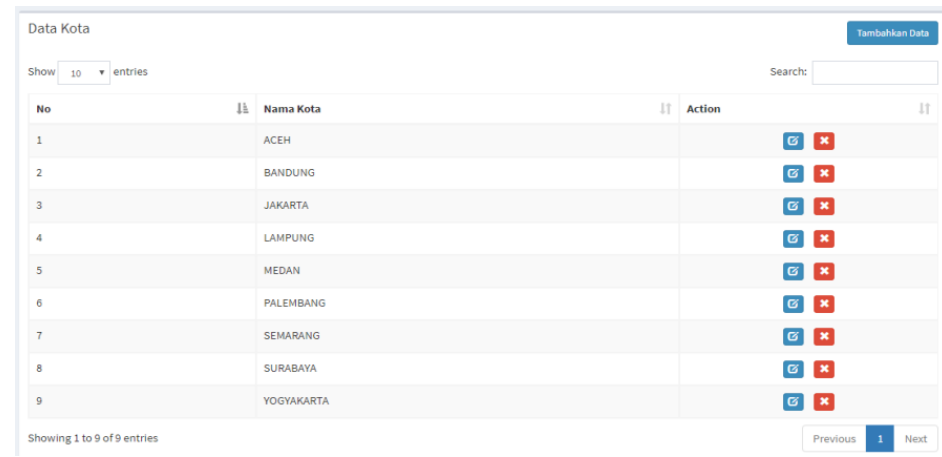

4. Tampil Halaman Kategori

Halaman data kategori merupakan halaman yang digunakan untuk menampikan informasi data kategori. Berikut tampilan halaman Data Kategori terlihat pada Gambar 5.

Gambar 5. Halaman Kategori

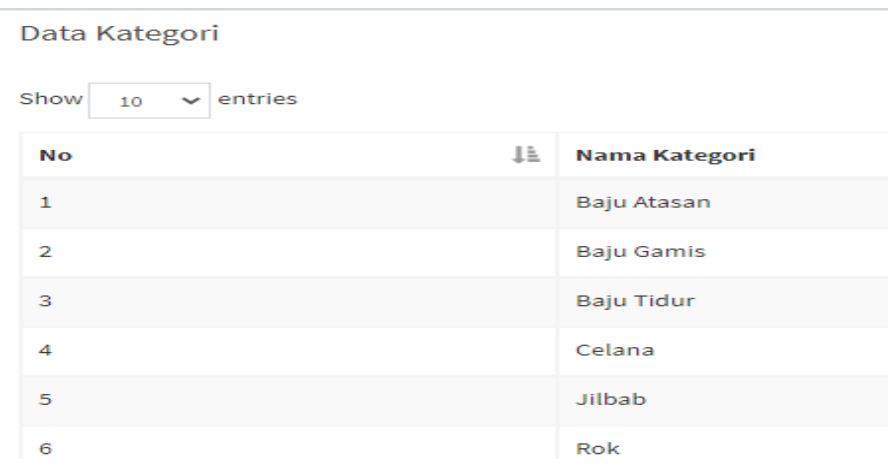

5. Tampil Halaman Pelanggan

Halaman data pelanggan merupakan halaman yang digunakan untuk menampikan informasi data pelanggan yang sudah registrasi ke dalam sistem. Berikut tampilan halaman data pelanggan terlihat pada Gambar 6.

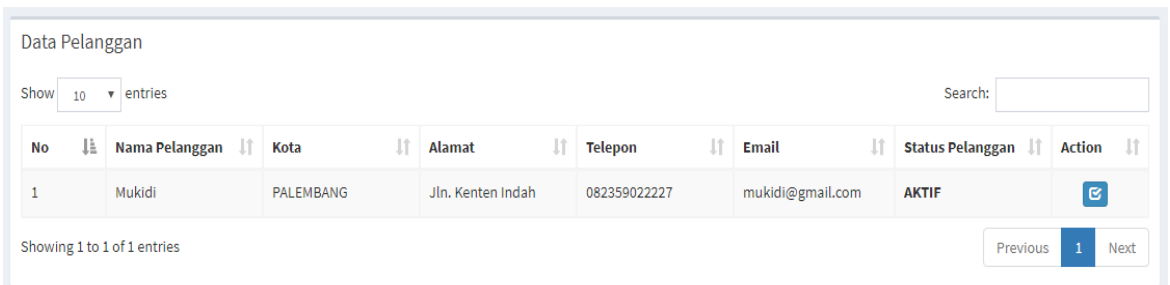

Gambar 6. Halaman Pelanggan

6. Tampil Halaman Order Pemesanan

Halaman data order pemesanan merupakan halaman yang diigunakan untuk menampikan informasi data pemesanan dari pelanggan. Berikut tampilan halaman data order pemesanan terlihat pada Gambar 7. 


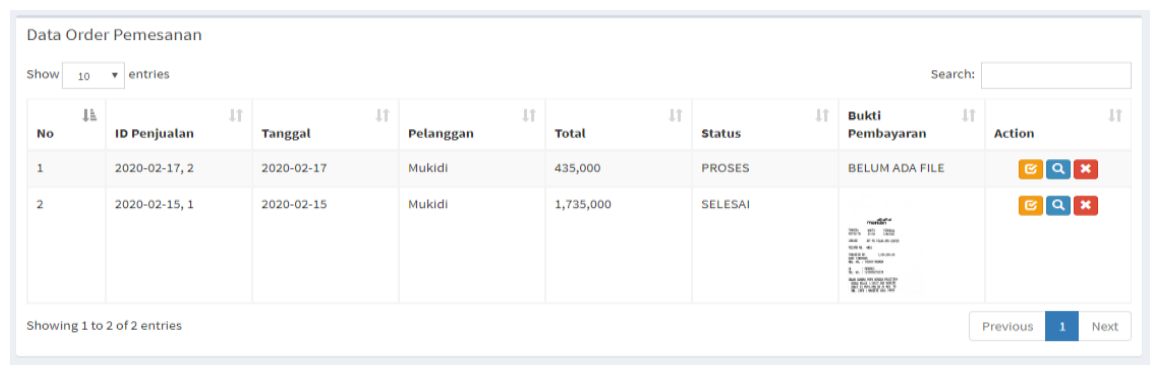

Gambar 7. Halaman Order Pemesanan

7. Tampil Halaman Laporan Barang

Halaman laporan barang merupakan halaman yang diigunakan untuk mencetak data laporan barang. Berikut tampilan halaman laporan barang terlihat pada Gambar 8 .

\begin{tabular}{|c|c|c|c|c|c|c|c|}
\hline \multirow[b]{2}{*}{ No } & \multicolumn{7}{|c|}{$\begin{array}{l}\text { DK CORNER } \\
\text { Data Barang }\end{array}$} \\
\hline & Nama Barang & Kategori & Merk & Harga & Diskon \% & $\begin{array}{l}\text { Harga } \\
\text { Bersih }\end{array}$ & Stock \\
\hline 1 & Bella Square & Jilbab & Segiempat & 18,000 & $30 \%$ & 12,600 & 200 \\
\hline 2 & Bergo Maryam & Jilbab & Bergo & 20,000 & $30 \%$ & 14,000 & 4,000 \\
\hline 3 & Blouse korean & Baju Atasan & Miroir & 145,000 & $60 \%$ & 58,000 & 100 \\
\hline 4 & Celina Big Size & Baju Atasan & Miroir & 120,000 & $43 \%$ & 68,400 & 200 \\
\hline 5 & DRESS DEYA & Baju Gamis & Hijabchic & 154,000 & $62 \%$ & 58,520 & 200 \\
\hline 6 & Hanley Long Shirt & Baju Atasan & Miroir & 70,000 & $5 \%$ & 66,500 & 150 \\
\hline 7 & hijab pasmina $175 \times 75$ & Jilbab & Pasmina & 20,000 & $21 \%$ & 15,800 & 500 \\
\hline 8 & JEANS WANITA & Celana & Jeans & 100,000 & $15 \%$ & 85,000 & 70 \\
\hline 9 & Lala Set Blouse & Baju Atasan & Miroir & 90,000 & $20 \%$ & 72,000 & 200 \\
\hline 10 & Mecca Gamis Syari & Baju Gamis & Hijabchic & 160,000 & $31 \%$ & 110,400 & 150 \\
\hline 11 & MELVA SLIT & Celana & Miroir & 84,000 & $29 \%$ & 59,640 & 150 \\
\hline 12 & PASMINA SABYAN & Jilbab & Pasmina & 19,000 & $24 \%$ & 14,440 & 200 \\
\hline 13 & PIYAMA DEWASA & Baju Tidur & Miroir & 70,000 & $20 \%$ & 56,000 & 60 \\
\hline 14 & Piyama Wanita & Baju Tidur & Miroir & 80,000 & $30 \%$ & 56,000 & 60 \\
\hline 15 & Plain Dress jersey & Baju Gamis & Hijabchic & 90,000 & $25 \%$ & 67,500 & 250 \\
\hline 16 & Rok Plisket premium & Rok & Miroir & 50,000 & $20 \%$ & 40,000 & 200 \\
\hline 17 & SYARI JUMBO & Baju Gamis & Hijabchic & 200,000 & $50 \%$ & 100,000 & 200 \\
\hline 18 & Yanda Skirt & Rok & Miroir & 160,000 & $5 \%$ & 152,000 & 150 \\
\hline
\end{tabular}

Gambar 8. Halaman Laporan Barang

8. Tampil Halaman Laporan Penjualan

Halaman laporan penjualan merupakan halaman yang diigunakan untuk menampilkan informasi data penjualan. Berikut tampilan halaman laporan penjualan terlihat pada Gambar 9.

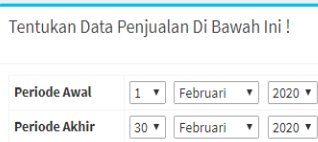

Gambar 9. Halaman Laporan Penjualan 
DK CORNER

Data Transaksi Penjualan

\begin{tabular}{|l|r|r|l|l|l|l|}
\hline $\mathbf{N}_{\mathbf{0}}$ & ID Penjualan & Tanggal & \multicolumn{1}{c|}{ Pelanggan } & 0ngkir & \multicolumn{1}{c|}{ Total } & Grand Total \\
\hline 1 & $2021-10-09,3$ & $2021-10-09$ & Wahyu Hartowi & 27,000 & 58,000 & 85,000 \\
\hline 2 & $2021-10-09,2$ & $2021-10-09$ & Wahyu Hartowi & 27,000 & 152,000 & 179,000 \\
\hline 3 & $2021-10-09,1$ & $2021-10-09$ & Wahyu Hartowi & 27,000 & 12,600 & 39,600 \\
\hline
\end{tabular}

Palembang, 11-10-2021

Gambar 10. Halaman Cetak Transaksi Penjualan

9. Tampilan Halaman User

Halaman user merupakan halaman yang diigunakan untuk menampikan informasi data pengelola sistem yang berhak menjalankan sistem. Berikut tampilan halaman data pengelola sistem terlihat pada Gambar 11.

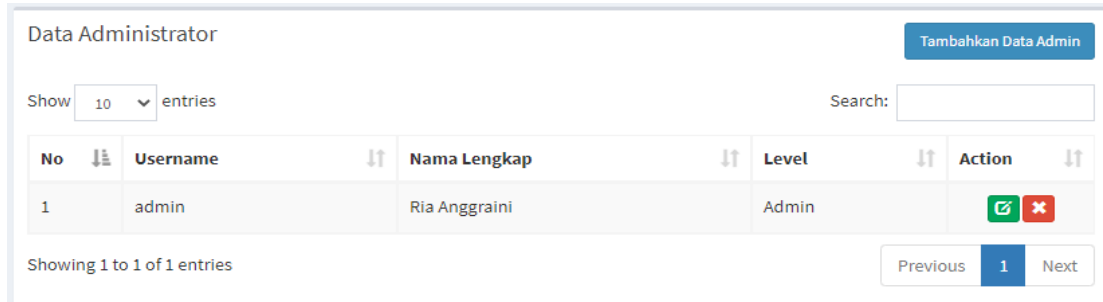

Gambar 11.Halaman User

\subsection{Antar Muka Bagi Pelanggan}

Halaman antar muka bagi pelanggan merupakan halaman depan yang hanya khusus untuk pelanggan dalam mencari informasi produk serta transaksi pemesanan. Berikut halaman antar muka bagi Pelanggan.

1. Halaman Registrasi

Halaman Registrasi akan tampil pertama setelah pelanggan berhasil login Untuk halaman Dashboard dapat dilihat pada Gambar 12.

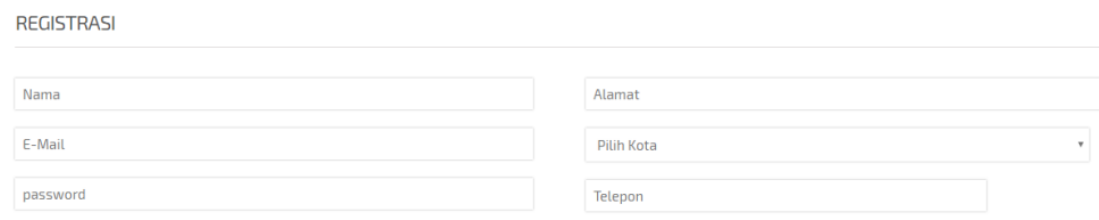

Gambar 12. Halaman Registrasi 
2. Halaman Login

Halaman Login akan tampil pertama kali jika pengelola sistem masuk ke dalam sistem. Untuk halaman Login dapat dilihat pada Gambar 13.

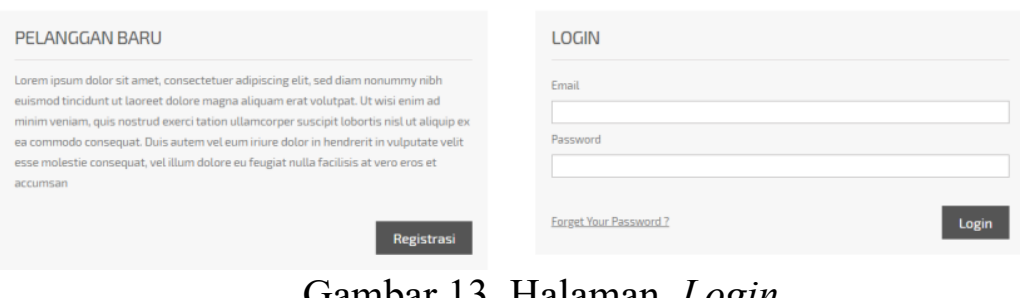

Gambar 13. Halaman Login

3. Halaman Akun Saya

Halaman Akun Saya merupakan halaman yang dapat digunakan pelanggan untuk mengedti profile mereka kedalam sistem. Untuk halaman Akun Saya dapat dilihat pada Gambar 14.

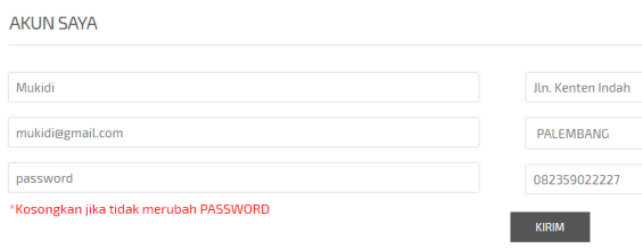

Gambar 14. Halaman Akun Saya

\section{Tampil Halaman Home}

Halaman Home merupakan halaman yang tampil awal ketika website diakses pelanggan. Berikut tampilan halaman Home terlihat pada Gambar 15.

Gambar 15. Halaman Home

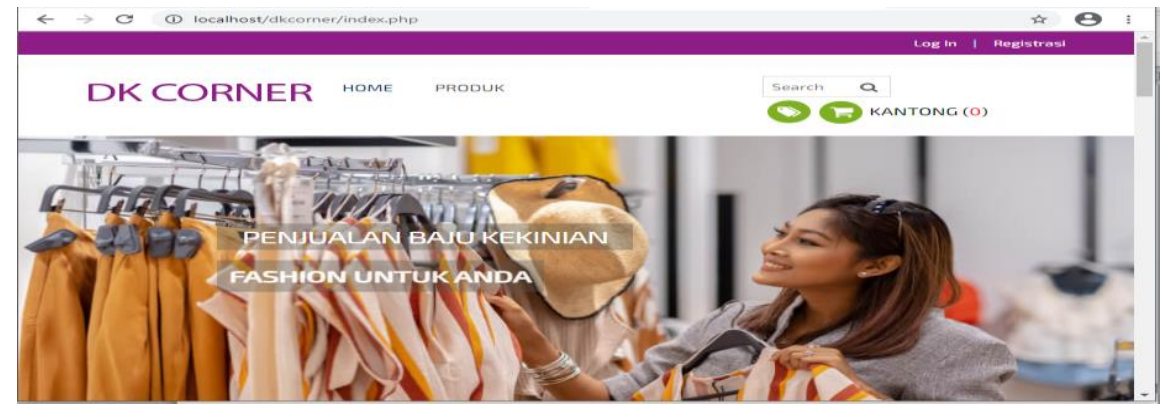

5. Halaman Informasi Produk

Halaman informasi produk digunakan pelanggan untuk melihat data produk yang tersedia. Untuk halaman Informasi produk dapat dilihat pada Gambar 16. 


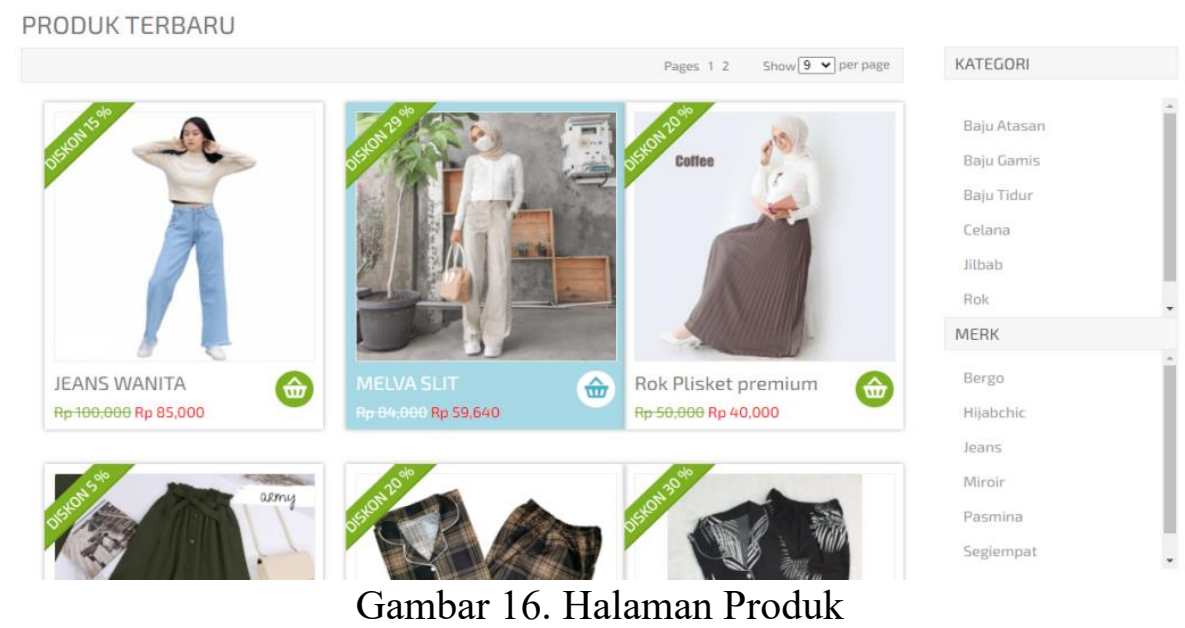

6. Halaman Kantong Belanja

Halaman kantong belanja merupakan halaman yang menampilkan informasi produk yang dibeli pelanggan. Untuk halaman kantong belanja dapat dilihat pada Gambar 17.

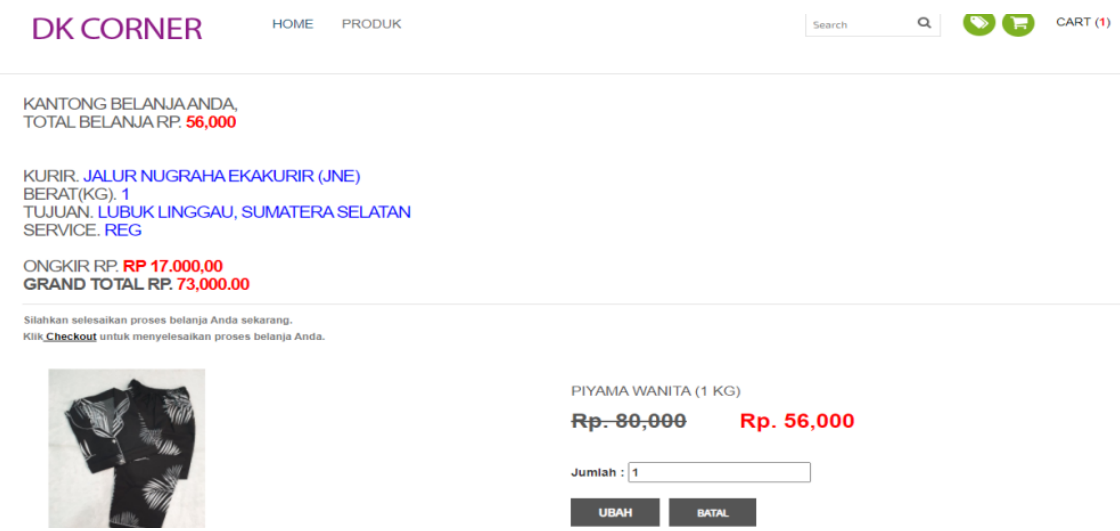

Gambar 17. Halaman Kantong Belanja

7. Halaman Transaksi

Halaman transaksi merupakan halaman yang menamplkan history transaksi yang pernah dilakukan pelanggan. Untuk halaman transaksi dapat dilihat pada Gambar 18.

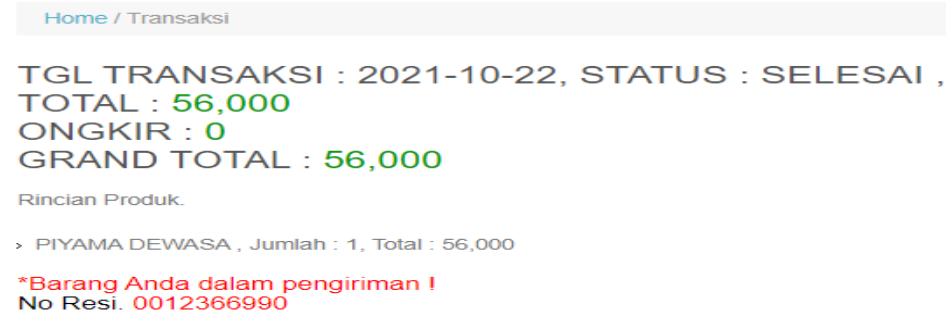

Gambar 18. Halaman Transaksi

Pada halaman transaksi terdapat tombol aksi "Upload Bukti Pembayaran", pada transaksi yang berstatus Konfirmasi Pembayaran yang digunakan pelanggan unntuk mengupload bukti bayar kedalam sistem website. Untuk halaman transaksi dapat dilihat pada Gambar 19. 
TGL TRANSAKSI : 2020-02-17, STATUS : KONFIRMASI PEMBAYARAN, TOTAL : 435,000

Rincian Produk

> Burundi, Jumlah : 1, Total: 435.000

Masukkan bukti bayar Anda!

Choose File No file chosen

UPLOAD BUKTI BAYAR

Gambar 19. Halaman Konfirmasi Bayar

8. Halaman Tentang Kami

Halaman tentang kami merupakan halaman yang menampilkan inormasi mengenai Toko DK Corner. Untuk halaman tentang kami dapat dilihat pada Gambar 20.

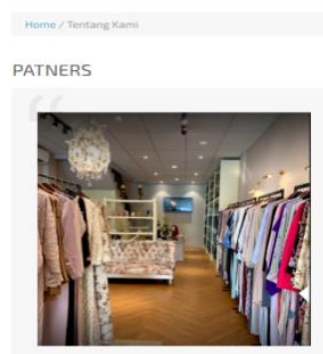

TENTANG KAMI
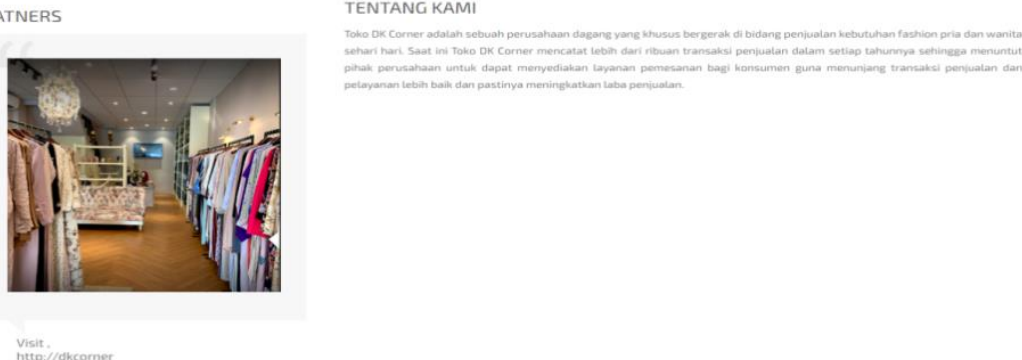

Gambar 20. Halaman Tentang Kami

9. Halaman Hubungi Kami

Halaman hubungi kami merupakan halaman yang menampilkan kontak mengenai Toko DK Corner. Untuk halaman hubungi kami dapat dilihat pada Gambar 21.

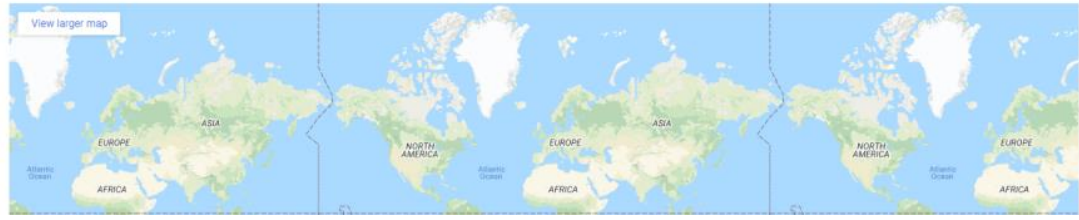

Gambar 21. Halaman Hubungi Kami

\section{Kesimpulan}

Berdasarkan penelitian yang dilakukan dan hasil pembahasan yang diuraikan pada babbab sebelumnya, maka dapat ditarik kesimpulan sebagai berikut: 
1. Dengan adanya Webstore online pada toko DK Corner dapat memperluas angkauan pasar tidak hanya di daerah lubuk linggau saja tapi bisa di seluruh Indonesia bahkan ke luar negeri;

2. Dengan adanya pengembangan penjualan menjadi sistem Webstore online berbasis web, diharapkan dapat lebih mudah mengelola data yang berhubungan dengan penjualan produk serta jangkauan pasar yang luas serta dapat mengatasi kekurangan pada sistem yang lama.

\section{Referensi}

Abdullah, Rohi. 2015. Web Programing is Easy. Elek Media Komputindo. Jakarta.

Adhiasta, M. R., \& Muhammad Kusban, S. T. (2016). Perancangan Informasi Batik Solo Berbasis Bootstrap (Doctoral dissertation, Universitas Muhammadiyah Surakarta).

Antoni, D., \& Akbar, M. (2019). E-supply chain management value concept for the palm oil industry. Jurnal Sistem Informasi, 15(2), 15-29.

Antoni, D., Fikari, D., \& Akbar, M. (2018). The readiness of palm oil industry in enterprise resource planning. Telkomnika, 16(6), 2692-2702.

Antoni, D., Herdiansyah, M. I., Akbar, M., \& Sumitro, A. (2021). Pengembangan Infrastruktur Jaringan Untuk Meningkatkan Pelayanan Publik di Kota Palembang. JURNAL MEDIA INFORMATIKA BUDIDARMA, 5(4), 1652-1659.

Antoni, D., Jie, F., \& Abareshi, A. (2020). Critical factors in information technology capability for enhancing firm's environmental performance: case of Indonesian ICT sector. International Journal of Agile Systems and Management, 13(2), 159-181.

Fauzi, F., Dencik, A. B., \& Asiati, D. I. (2019). Metodologi Penelitian untuk manajemen dan akuntansi. Jakarta: Salemba Empat.

https://journals.upi-yai.ac.id/index.php/ikraith-informatika/article/view/205/106 (diakses tanggal 20 Desember 2020).

I.Putu Agus Eka Pratama, 2014, Sistem Informasi dan Implementasinya, Informatika. Bandung.

Khumaidi, Ali. (2018). Perancangan Aplikasi Marketplace Order Baju Pintar Menggunakan Web Responsif Untuk Memudahkan Customer Mendesain Sesuai Selera.

Nilasari, Senja. 2014. Jago Membuat Website Gratis \& Cepat. Dunia Komputer. Jakarta.

Sopiah, N., \& Agustina, E. P. (2018). Penggunaan Metode Web Engineering dalam Aplikasi Penjualan Kain Khas Palembang. http://journal.binadarma.ac.id/index.php/jurnalmatrik/article/view/113/79 (diakses tanggal 20 Desember 2020).

Sujarweni, V. Wiratna. (2015). Sistem Akuntansi. Pustaka Baru Press. Yogyakarta. Sutabri Tata, 2012. Sistem Informasi Manajemen, Penerbit Andi. Yogyakarta. 


\section{Copyrights}

Copyright for this article is retained by the author(s), with first publication rights granted to the journal.

This is an open-access article distributed under the terms and conditions of the Creative Commons Attribution license (http://creativecommons.org/licenses/by/4.0/) 